\title{
Local Perceptions of Food Plants in Eastern Burkina Faso
}

\author{
K. Marie Laure Guissou, Thea Kristiansen, and \\ Anne Mette Lykke
}

\section{Research}

\begin{abstract}
Ethnobotanical interviews on the use of food plants were conducted with 90 informants from two villages in eastern Burkina Faso. A total of 25 plant species and one type of stock cube were included in a structured questionnaire regarding use, importance, reasons behind use, changes in use, and preferences, followed by a supplementary semi-structured questionnaire about reasons behind use, changes, and preferences. Most species were highly used and considered important. Adansonia digitata L., Bombax costatum Pellegr. \& Vuillet, Parkia biglobosa (Jacq.) R.Br. ex G.Don, and Vitellaria paradoxa C.F.Gaertn. were particularly important and useful species. Tradition, taste, health, and the lack of other possibilities were main reasons for people using the plants. A decline in traditional food products and an emergence of new products were observed. Answers were strongly related to informants' home-village and project-contact. There seems to be an extensive interest in health aspects and, consequently, a potential for an increased use of healthy traditional products if people are better informed about their nutritive qualities.
\end{abstract}

\section{Introduction}

Wild plants are traditionally eaten throughout West Africa, especially in rural areas. They are found in fallow areas and fields where trees deliberately are left growing and intercropping is common. A common dish is tô, a thick porridge from sorghum, millet, or maize, eaten with a vegetable sauce often including wild plants. Wild plants provide a nutritional contribution to an otherwise often monotonous diet (Ganaba et al. 2002, Millogo-Rasolodimby \& Guinko 1996), especially in places where the diet rarely includes meat, milk, or modern cultivated vegetables (Lykke et al. 2002, Mertz et al. 2001). Furthermore, wild plants may act as famine foods in periods of hardship (Flyman 2006, Humphry et al. 1993). Famine foods are (1) species that bear fruit or leaves at the end of the dry season and the beginning of the rainy season, when stocks from the last harvest are low, and (2) species with "heavy" leaves, which can make a sauce that is filling enough to be sufficient without tô.

Many studies have documented different uses of wild plants (Mbayngone \& Thiombiano 2011, Ouédraogo et al. 2013, Zerbo et al. 2011), one important use being food, but few studies have considered the reasons behind the choice of food plants. A decline of many useful plant species caused by decreased abundance in the landscape and even disappearance of a number of species in certain areas has been described (Wezel \& Lykke 2006). This may affect the food habits of people. In this context, people's choices and perceptions of their eating habits are important in order to understand whether species declining or disappearing in the local area are replaced by nutritionally equal species and whether food security is main-

\section{Correspondence}

K. Marie Laure Guissou, Ecole Normale Supérieure, Université de Koudougou, BP 376 Koudougou, BURKINA FASO.

Thea Kristiansen, Anne Mette Lykke, Department of Bioscience, Aarhus University, Vejlsøvej 25, 8660 Silkeborg, DENMARK.

Ethnobotany Research \& Applications 14:199-209 (2015)

Published: 05 August 2015 


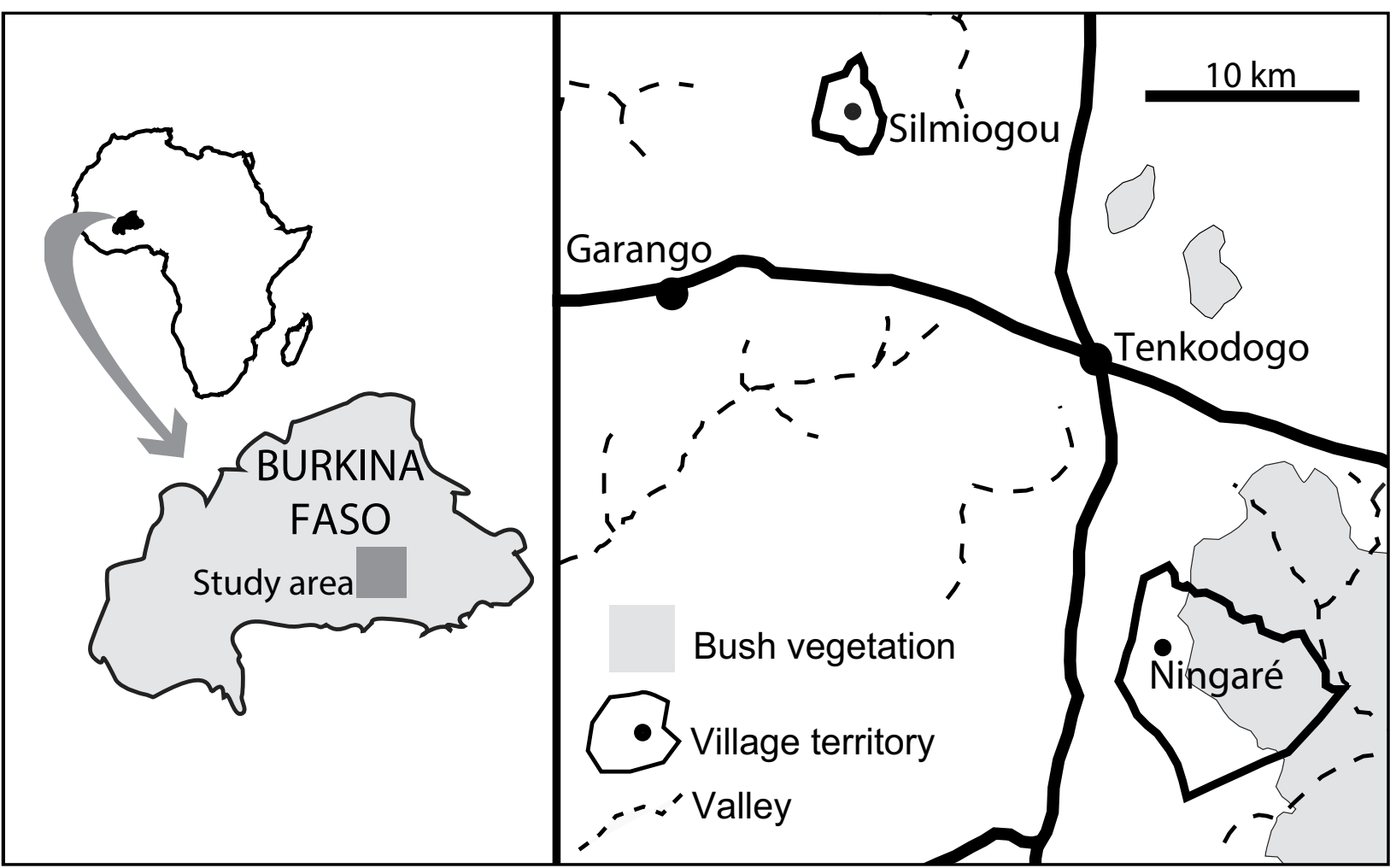

Figure 1. Location of Silmiogou and Ningaré villages near Tenkodogo, Boulgou Province, Burkina Faso.

tained. Quantitative interviews are one way of obtaining information about local knowledge, habits, use, and preferences (Alexiades 1996, Lykke et al. 2004).

Two villages, Silmiogou and Ningaré in eastern Burkina Faso, participated in a diary-study in 1996-97, where the importance of wild plants in the daily food-intake was documented (Lykke et al. 2002, Mertz et al. 2001). Several underused species were pointed out, as well as an increased use of manufactured products, with significant differences between villages. The present study builds on a series of structured and semi-structured interviews from the same two villages. The purpose is to look into local people's use of food species, reasons behind choice of food species, changes in food habits, and factors that might influence people's choice.

\section{Study area}

Burkina Faso is characterized by a seasonal tropical climate, with a rainy season from June to September and large inter-annual variations in rainfall. The study area, including the villages of Silmiogou and Ningaré, is situated in the Sudanian zone (Guinko 1984). Silmiogou is slightly wealthier and more developed as several rural development projects have provided more assistance than in Ningaré (Hansen \& Reenberg 1998, Mertz \& Reenberg 1999). The nearest town, Tenkodogo, is about $15 \mathrm{~km}$ away (Figure 1). The two major ethnic groups in both villages are the Mossi and Bissa, and most people understand Moré. People live and eat together in households of about 5-25 people. They cultivate a mixture of traditional crops such as sorghum and millet, cash crops such as ground nuts, cotton, and tobacco, and keep livestock.

\section{Methods}

Interviews were conducted on 25 food plants (10 trees, 3 shrubs, 11 herbs, 1 liana) and stock cubes (maggi) (in the following referred to as the $26^{\text {th }}$ "species"). These species were included in the previous diary study and were meant to represent a broad selection of trees, herbs, wild, and cultivated species. Although maggi is a manufactured product, it was included because it is used in every village throughout Burkina Faso, often as a substitute for soumbala, the traditional preparation of boiled and fermented seeds of Parkia biglobosa (Jacq.) R.Br. ex G.Don. The latter is an aromatic, tasty seasoning, rich in lipids, protein, and carbohydrates and is a good source of fat and calcium (Ntui et al. 2012). Maggi is a nutritionally poorer food than soumbala, and a replacement leads to decline in local health. 
Table 1. Species included in structured interviews of villagers from Silmiogou and Ningaré, Boulgou Province, Burkina Faso. Part used: (fl) flowers, (fr) fruits, (l) leaves, (se) seeds. Parts used by villagers in general in the region but not asked for in this study are given in brackets. Source: (c) cultivated, (b) bought, (fo) forest, (fi) field. Origin: (n) native, (e) exotic. Lifeform: (t) tree, (s) shrub, (c) woody climber, (h) herb. Season, the period of highest use: (r) rainy season, (d) dry season, (d/r) end of dry and beginning of rainy season, (a) used equally frequent all year.

\begin{tabular}{|c|c|c|c|c|c|c|c|}
\hline Species & Family & $\begin{array}{l}\text { Vernacular names } \\
\text { English/Moré }\end{array}$ & $\begin{array}{l}\text { Part } \\
\text { used }\end{array}$ & 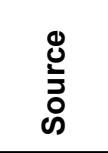 & 흔 & 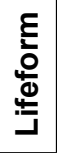 & 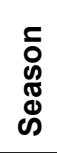 \\
\hline Adansonia digitata L. & Malvaceae & Baobab/Toeega & $\mathrm{l}(\mathrm{fr})$ & fo, fi & $\mathrm{n}$ & $\mathrm{t}$ & $r$ \\
\hline Allium cepa L. & Amaryllidaceae & Onion/Zãyõ & 1 & $\mathrm{c}, \mathrm{fi}, \mathrm{b}$ & e & $\mathrm{h}$ & $\mathrm{a}$ \\
\hline Amaranthus hybridus L. & Amaranthaceae & Smooth pigweed/Lisambo & 1 & $c, f i, b$ & $\mathrm{e}$ & $\mathrm{h}$ & a \\
\hline $\begin{array}{l}\text { Annona senegalensis } \\
\text { Pers. }\end{array}$ & Annonaceae & Wild custard-apple/Barkudi & $\begin{array}{l}\mathrm{fl}, \mathrm{l} \\
(\mathrm{fr})\end{array}$ & fo & $\mathrm{n}$ & $\mathrm{s}$ & $r$ \\
\hline $\begin{array}{l}\text { Bombax costatum Pellegr. } \\
\text { \& Vuillet }\end{array}$ & Malvaceae & Red-flowered silk-cotton/Vaaga & $\mathrm{fl}$ & fo, fi & $\mathrm{n}$ & $\mathrm{t}$ & $d$ \\
\hline Boscia senegalensis Lam. & Capparaceae & Senegal boscia/Zelgo & 1 & fo, fi & $\mathrm{n}$ & s & $r$ \\
\hline Capsicum annuum L. & Solanaceae & Chili/Kipare & $\mathrm{fr}$, se & $c, f i, b$ & e & $\mathrm{h}$ & a \\
\hline $\begin{array}{l}\text { Ceratotheca sesamoides } \\
\text { Endl. }\end{array}$ & Pedaliaceae & False sesame/Bundu & I & fo, fi & $\mathrm{n}$ & $\mathrm{h}$ & $r$ \\
\hline Cleome gynandra L. & Cleomaceae & Spiderplant/Kelebdo & 1 & $c, f i, b$ & $\mathrm{n}$ & $\mathrm{h}$ & $r$ \\
\hline Commelina sp. & Commelinaceae & Commelina/Tak boanga & 1 & $\mathrm{fi}$ & $\mathrm{n}$ & $\mathrm{h}$ & $r$ \\
\hline Corchorus sp. & Malvaceae & Mallow/Bulvaka & 1 & $\mathrm{c}, \mathrm{fi}$ & $\mathrm{n}$ & $\mathrm{h}$ & $a$ \\
\hline $\begin{array}{l}\text { Detarium microcarpum } \\
\text { Guill. \& Perr. }\end{array}$ & Fabaceae & Sweet dattock/Kankare & $\mathrm{fr}$ & fo & $\mathrm{n}$ & $\mathrm{t}$ & $d$ \\
\hline $\begin{array}{l}\text { Diospyros mespiliformis } \\
\text { Hochst. ex A.DC. }\end{array}$ & Ebenaceae & Jackal-berry/Ganka & $\mathrm{fr}$ & fo, fi & $\mathrm{n}$ & $\mathrm{t}$ & $d$ \\
\hline Hibiscus cannabinus L. & Malvaceae & Kenaf/Berga & 1 & $\mathrm{c}, \mathrm{fi}$ & $\mathrm{e}$ & $\mathrm{h}$ & $r$ \\
\hline Hibiscus sabdariffa L. & Malvaceae & Roselle/Bisape & $\mathrm{fl}(\mathrm{l})$ & $\mathrm{c}, \mathrm{fi}$ & $\mathrm{e}$ & $\mathrm{h}$ & $a$ \\
\hline Ipomoea eriocarpa R.Br. & Convolvulaceae & Gilgito & I & $\mathrm{fi}$ & $\mathrm{n}$ & $\mathrm{h}$ & $r$ \\
\hline Lannea microcarpa Engl. & Anacardiaceae & African grape/Sibga & $\mathrm{fr}$ & fo, fi & $\mathrm{n}$ & $\mathrm{t}$ & $d / r$ \\
\hline Leptadenia hastata Vatke & Apocynaceae & Lelengo & 1 & fo, fi & $\mathrm{n}$ & $\mathrm{C}$ & $\mathrm{a}$ \\
\hline $\begin{array}{l}\text { Lycopersicon esculentum } \\
\text { Mill. }\end{array}$ & Solanaceae & Tomato/Tomato & $\mathrm{fr}$ & $c, f i, b$ & e & $\mathrm{h}$ & a \\
\hline Maggi & & Maggi & - & $\mathrm{b}$ & - & - & a \\
\hline $\begin{array}{l}\text { Parkia biglobosa (Jacq.) } \\
\text { R.Br. ex G.Don }\end{array}$ & Fabaceae & African locust bean/Kolgo & se (fr) & $\begin{array}{l}\text { fo, } \\
\text { fi, b }\end{array}$ & $\mathrm{n}$ & $\mathrm{t}$ & a \\
\hline Strychnos spinosa Lam. & Loganiaceae & Kaffir orange/Katenpoanega & $\mathrm{fr}(\mathrm{I})$ & fo & $\mathrm{n}$ & $\mathrm{t}$ & $\mathrm{d}$ \\
\hline Tamarindus indica L. & Fabaceae & Tamarind/Pusa & $\mathrm{fr}$ & fo, fi & $\mathrm{n}$ & $\mathrm{t}$ & $\mathrm{a}$ \\
\hline $\begin{array}{l}\text { Vitellaria paradoxa } \\
\text { C.F.Gaertn. }\end{array}$ & Sapotaceae & Shea/Taama & $\mathrm{fr}$ & fo, fi & $\mathrm{n}$ & $\mathrm{t}$ & $d$ \\
\hline Vitex doniana Sweet & Lamiaceae & Black plum/Anto & $\mathrm{I}, \mathrm{fr}$ & fo, fi & $\mathrm{n}$ & $\mathrm{t}$ & $r$ \\
\hline Ziziphus mauritiana Lam. & Rhamnaceae & Indian jujube/Muglga & $\mathrm{fr}$ & fo, fi & $\mathrm{n}$ & $\mathrm{s}$ & $\mathrm{d}$ \\
\hline
\end{tabular}

This study focuses primarily on wild species, but a few cultivated species have been included for comparison (Table 1). Interviews were conducted with 47 informants from Silmiogou and 43 informants from Ningaré from October to November 2004 (Table 2). In each village, 12 households were selected, and interviews were preferably made with two women and two men from each household. The se- lection of informants was made in collaboration with the village leader and family chiefs. Households from all parts of the village and adults of different ages were selected as informants in order to give as full a representation as possible. Households taking part in the study by Lykke et al. (2002) took part in the present study, and the questionnaire and the selection of species were based on this 
Table 2. Demographics of informants from Silmiogou and Ningaré villages, Boulgou Province, Burkina Faso.

\begin{tabular}{ll}
\hline Personal characteristic & Response categories \\
\hline Village & Silmiogou $=47$; Ningaré $=43$ \\
Have contact with project of rural development & No contact $=44 ;$ contact $=46$ \\
Have contact with city & No contact $=27$; contact $=63$ \\
Forest & No-/little importance $=36$; large importance $=54$ \\
Collection frequency of wild food species & Rarely/never $=28 ;$ almost every day/about once a week = 62 \\
Relative wealth (ownership of land, animals, plough, & Low $=32 ;$ medium $=33 ;$ high $=25$ \\
\multicolumn{1}{c}{ cart, moped, and ability to invite guest labor) } & \\
Ethnic group & Mossi $=37 ;$ Bissa $=53$ \\
Gender & Women $=45 ;$ men $=45$ \\
Age & Young $=40 ;$ old $=50$ \\
Religion & Muslim $=74 ;$ Catholic $=7 ;$ Protestant $=9$ \\
Have lived in another village & No $=47 ;$ yes $=43$ \\
Have lived in another country & No $=65 ;$ yes $=25$ \\
\hline
\end{tabular}

work. Interviews were carried out directly in the language Moré, spoken by all informants. Names of plant families follow the Angiosperm Phylogeny Group (APG 2009).

Each interview consisted of two parts. The first part was highly structured, including 26 species, focusing on use (not used, used a little, used a lot) and reasons behind use: tradition, taste, health, new product, and no other choice (not a reason, a minor reason, a main reason). Informants were asked of each species: "Would it be used more if it was more available/you had more money?" (no, a little, a lot), "Is it used more/less now than in former times?" (more, same, less), and "Relative to current use, do you prefer to use it more/less?" (more, same, less). The sequence of species varied from questionnaire to questionnaire in order to avoid systematically biased answers. Finally, informants were asked to point out the most appreciated species in general, in the dry season, and as famine foods, among those included in the structured questionnaire. Three extra species (Balanites aegyptica (L.) Delile, Celosia argentea L., and Cryptolepis sanguinolenta (Lindl.) Schltr.) were included in the question about famine foods.

The second part of the interview was semi-structured and covered questions about changes in food habits and people's preferences. Informants were asked to mention the most important reasons when choosing plants to eat and about the reasons for not always eating their most preferred food. Finally informants were asked "why?" every time a species was reported as not used and were there- after asked to mention reasons for using each of the 26 species. These answers were categorized by identifying and counting similar answers, also including information given during informal discussions with the villagers, interpreters, and other local people alongside interviews.

Personal characteristics concerning village, age, gender, ethnic group, religion, collection frequency of wild food species, and view on importance of the forest as a food source were recorded for each informant. Different parameters of outward contact (contact with cities, other villages, other countries or projects) and relative wealth (ownership of land, animals, plough, cart, moped, and ability to invite guest labor) were also included.

In order to investigate whether personal characteristics were influencing answers, we performed $\mathrm{G}^{2}$ tests ( $\alpha$-level $=0.01$ ) for each of the 26 species individually. Six variables (use and the five reasons for use) were tested against twelve personal characteristics (Table 2) (e.g., does age influence informants' use of $P$. biglobosa). The variable "age" was collapsed into two groups (young, old), separating informants by the median 45 years. Estimations of wealth were collapsed into three groups (low, medium, high).

Since a few species were unknown to some informants, their answers were coded as "not used" and "not a reason" for the relevant questions. Boscia senegalensis Lam., Commelina sp., and Leptadenia hastata Vatke were unknown to 20,3, and 5 informants, respectively. Answers 


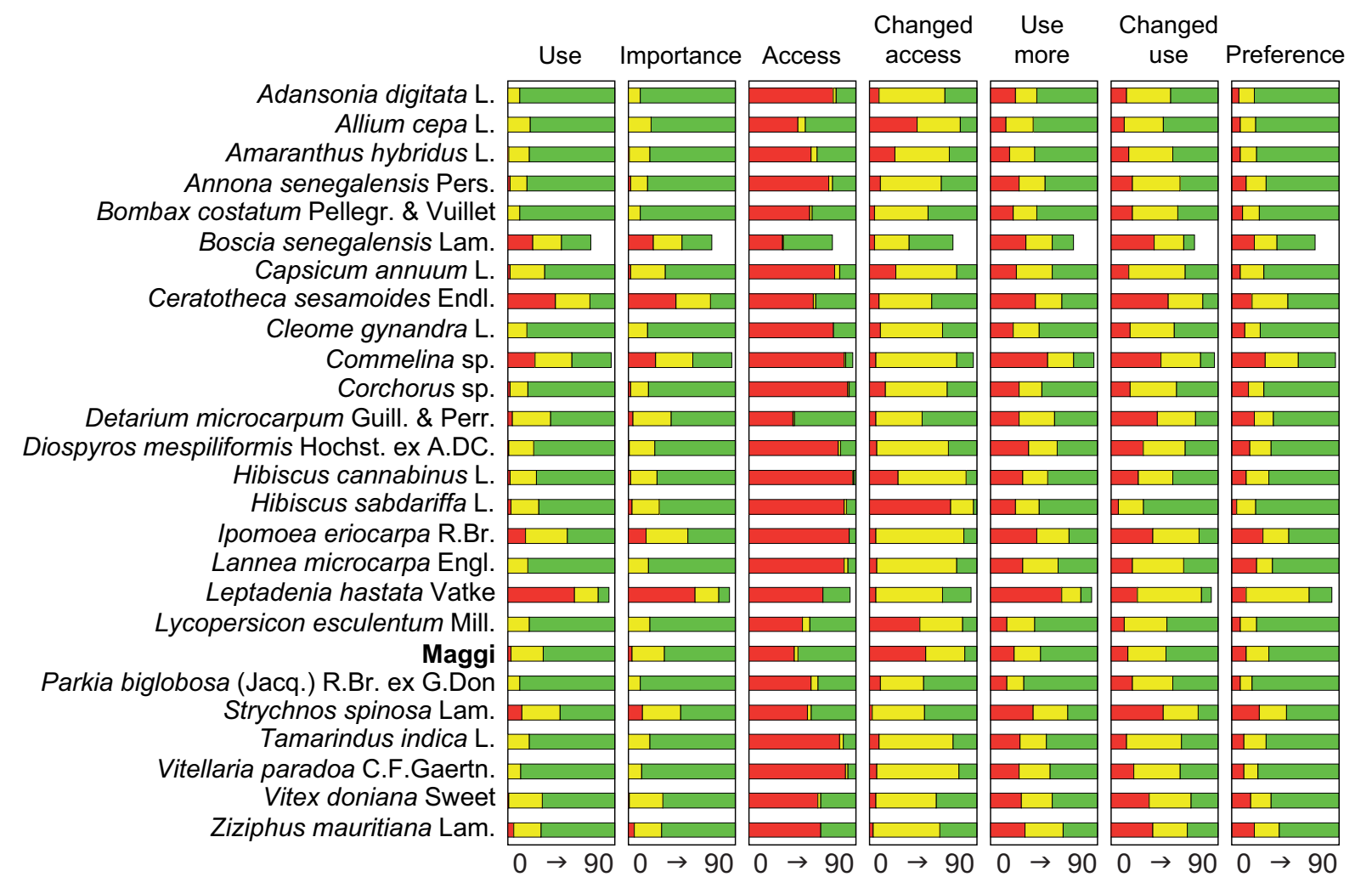

Figure 2. Informant responses per species for use, importance, access, change in access, if the species would be used more if it were more available/if informants had more money, changed use, and preferences for use as reported by villagers from Silmiogou and Ningaré, Boulgou Province, Burkina Faso. The $x$-axis shows the number of informants from 0 to 90 . Shorter bars indicate that the species was unknown to some informants. Red, yellow, and green bars correspond to the following categories: Use = not used, used a little, used a lot; Importance = not, a little, very important; Access = easy, medium, difficult to access; Changed access = easier, same, harder to access; Use more (if it were more available/ if informants had more money) $=$ no, a little, a lot; Changed use and preference $=$ less, same, more .

for reasons were collapsed into fewer categories than originally asked for (not a reason, a reason) because the category "a minor reason" was rarely used.

\section{Results}

Many of the plants were used for a traditional African vegetable sauce, e.g., Adansonia digitata L., Amaranthus hybridus L., Annona senegalensis Pers., Bombax costatum Pellegr. \& Vuillet, Corchorus sp., Hibiscus cannabinus L., $P$. biglobosa, and Vitex doniana Sweet. The fruits of $A$. digitata, Detarium microcarpum Guill. \& Perr., Diospyros mespiliformis Hochst. ex A.DC., Lannea microcarpa Engl., Strychnos spinosa Lam., V. doniana, and Ziziphus mauritiana Lam. were eaten as snacks between meals while Tamarindus indica $\mathrm{L}$. was used for preservation of tô, the flowers of Hibiscus sabdariffa L. were used for a sweetened drink called bisape, and maggi was used to flavor the sauce. A few informants reported Ceratotheca sesamoides Endl. as children's food and Capsicum annuum $L$. to be for adults.
The structured questionnaires showed that most species were used a lot and considered very important by nearly all informants (Figure 2). Boscia senegalensis, C. sesamoides, Commelina sp., Ipomoea eriocarpa R.Br., L. hastata, and S. spinosa stood out as less used and were considered less important by several informants. Accessibility was generally thought to be easy for most species, with a few such as Allium cepa L., B. senegalensis, D. microcarpum, maggi, and $S$. spinosa reported as difficult to get by nearly half of the informants. In many cases, accessibility was considered unchanged in the time people remember, but $44-76 \%$ of the informants found $A$. cepa, H. sabdariffa, Lycopersicon esculentum Mill., and maggi easier to obtain now, while $41-51 \%$ of the informants found B. costatum, B. senegalensis, $C$. sesamoides, D. microcarpum, P. biglobosa, and S. spinosa harder to obtain now.

Many informants wanted to use more of certain species if the species were easier to get or they had more money, most notably for $P$. biglobosa. On the contrary, most informants would not use more of Commelina sp. and $L$. hastata. Concerning change in use over time, the answers varied a lot among informants; Allium cepa, $H$. sabdariffa, $L$. esculentum, and maggi were often said to be used more, 


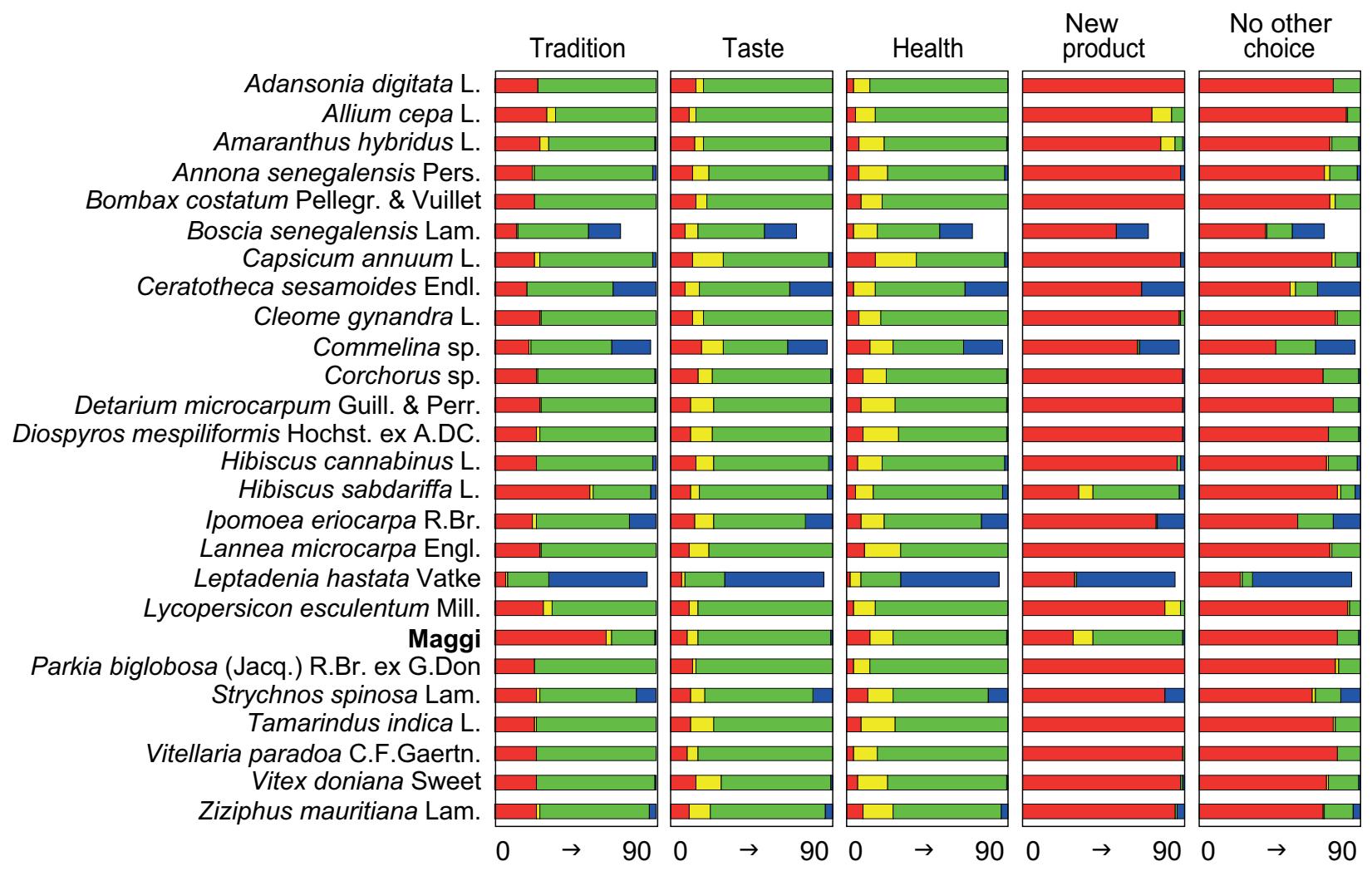

Figure 3. Reasons for using species as reported by villagers from Silmiogou and Ningaré, Boulgou Province, Burkina Faso. The $x$-axis shows the number of informants from 0 to 90 . Shorter bars indicate that the species was unknown to some informants. Red, yellow, green, and blue bars correspond to the following categories: not a reason, a minor reason, a major reason, and a species not ranked but still known to the informant.

while C. sesamoides, Commelina sp., and S. spinosa most often were said to be used less. When asked about preferences, informants mainly preferred to use more of all species, except Commelina sp., I. eriocarpa, and L. hastata (Figure 2).

Reasons for using a given species were consistent among most respondents (Figure 3). Tradition, taste, and health were considered by the majority of informants to be a main reason for using most species. Hibiscus sabdariffa and maggi were exceptions, as many informants did not find tradition to be a reason for use. Hibiscus sabdariffa and maggi stood out with more than half of the informants stating product novelty as a reason for use. Informants rarely used a species simply because they had no other choice: 48 informants did not report "no other choice" as a reason for using any of the species.

During semi-structured interviews, health, tradition, taste, and lack of other possibilities were most important when informants were asked about reasons for food choice in general terms. People preferred to eat plants that could give them strength and well-being. Likewise, health was often mentioned when asked about reasons for using single species, e.g., A. digitata. Accessibility was another important reason for using single species. In general, informants consumed species which were accessible (e.g., A. cepa, L. microcarpa, and maggi) whereas scarcity could lead to abandonment of food practices. For example, C. sesamoides was considered hard to find. When asked about the reasons for not eating their most preferred food, many informants mentioned the lack of other possibilities and poverty. This reason was particularly dominant in Ningaré. When informants were asked about reasons for not using a species, some mentioned that it was not their tradition (e.g., L. hastata). Nearly a third of the informants said that some wild species were not used, although they were accessible, because it was not the tradition to eat them and they did not like them.

There was a general perception of an ongoing change in food habits towards a decline in the use of traditional food plants and an emergence of new products. Informants preferred, on one hand, to keep using their traditional products while on the other they preferred to increase the use of new ones. People stressed the importance of access to enough food products to be able to vary the food in order to stay healthy. Comparing modern and traditional products in general based on information from the semi-structured interview, the majority held that modern products, such as tomatoes and salad, were better nutritionally. In contrast, some informants found that their nutrition is worse now due to the inclusion of more new products. Most people found taste to be improved due to more 
Table 3. Responses from Silmiogou and Ningaré villagers, Boulgou Province, Burkina Faso, regarding plant use, taste, and value relative to circumstances. (A) Differences among informant groups on use of plant species and on taste as a reason for choosing a species. $F=$ view on the importance of forest; $P=$ project-contact; $V=$ village. Only significant variables $(\alpha<0.01)$ are shown. $(B)$ The number of times a species was mentioned as most appreciated in general, in the dry season, and as famine food. ${ }^{1}$ The three species Balanites aegyptica (L.) Delile, Celosia argentea L., and Cryptolepis sanguinolenta (Lindl.) Schltr. were only included in the question about famine foods and not the rest of the questionnaire. ${ }^{2}$ Only the leaves of Vitex doniana Sweet are famine food.

\begin{tabular}{|c|c|c|c|c|c|}
\hline \multirow[b]{2}{*}{ Scientific name } & \multicolumn{2}{|c|}{ A } & \multicolumn{3}{|c|}{ B } \\
\hline & Use & Taste & $\begin{array}{l}\text { Appreciated, } \\
\text { general }\end{array}$ & $\begin{array}{l}\text { Appreciated, } \\
\text { dry season }\end{array}$ & $\begin{array}{l}\text { Famine } \\
\text { food }\end{array}$ \\
\hline Adansonia digitata L. & $\mathrm{P}$ & - & 41 & 40 & 5 \\
\hline Allium cepa L. & $\mathrm{P}, \mathrm{V}$ & $\mathrm{P}$ & 10 & 9 & - \\
\hline Amaranthus hybridus L. & - & - & 22 & 22 & 10 \\
\hline Annona senegalensis Pers. & $\mathrm{P}$ & - & 15 & 13 & 2 \\
\hline Balanites aegyptiaca (L.) Delile & & & - & 1 & $65^{1}$ \\
\hline Bombax costatum Pellegr. \& Vuillet & $\mathrm{P}$ & $\mathrm{P}$ & 55 & 45 & 3 \\
\hline Boscia senegalensis Lam. & $\mathrm{P}, \mathrm{V}$ & $\mathrm{V}$ & - & - & 7 \\
\hline Capsicum annuum L. & - & $\mathrm{P}$ & 8 & 3 & - \\
\hline Celosia argentea L. & 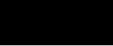 & 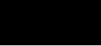 & - & - & $36^{1}$ \\
\hline Ceratotheca sesamoides Endl. & - & - & 3 & - & - \\
\hline Cleome gynandra L. & - & $\mathrm{P}$ & 22 & 16 & 19 \\
\hline Commelina sp. & - & - & 1 & - & 22 \\
\hline Corchorus sp. & $\mathrm{P}$ & $\mathrm{P}$ & 40 & 40 & 4 \\
\hline Cryptolepis sanguinolenta (Lindl.) Schltr. & & & - & - & $62^{1}$ \\
\hline Detarium microcarpum Guill. \& Perr. & $\mathrm{P}, \mathrm{V}$ & $\mathrm{P}, \mathrm{V}$ & 6 & 1 & 2 \\
\hline Diospyros mespiliformis Hochst. ex A.DC. & $\mathrm{F}, \mathrm{V}$ & $\mathrm{P}$ & 12 & 3 & 4 \\
\hline Hibiscus cannabinus L. & $\mathrm{P}, \mathrm{V}$ & $\mathrm{P}$ & 18 & 19 & 67 \\
\hline Hibiscus sabdariffa L. & $\mathrm{P}, \mathrm{V}$ & $\mathrm{P}$ & 5 & - & - \\
\hline Ipomoea eriocarpa R.Br. & - & - & 3 & 1 & 36 \\
\hline Lannea microcarpa Engl. & $\mathrm{F}, \mathrm{V}$ & $\mathrm{P}, \mathrm{V}$ & 13 & 2 & 7 \\
\hline Leptadenia hastata Vatke & $F$ & - & - & - & 7 \\
\hline Lycopersicon esculentum Mill. & - & $\mathrm{P}$ & 11 & 8 & - \\
\hline Maggi & - & $\mathrm{P}$ & 12 & 5 & - \\
\hline Parkia biglobosa (Jacq.) R.Br. ex G.Don & $\mathrm{P}$ & $\mathrm{P}, \mathrm{V}$ & 16 & 8 & - \\
\hline Strychnos spinosa Lam. & $\mathrm{V}$ & $\mathrm{P}$ & 6 & 1 & 12 \\
\hline Tamarindus indica L. & $F, P, V$ & $\mathrm{P}$ & 3 & 1 & 1 \\
\hline Vitellaria paradoxa C.F.Gaertn. & $\mathrm{V}$ & $\mathrm{P}, \mathrm{V}$ & 21 & 2 & 9 \\
\hline Vitex doniana Sweet & - & - & 6 & 1 & $16^{2}$ \\
\hline Ziziphus mauritiana Lam. & $\mathrm{F}, \mathrm{P}, \mathrm{V}$ & - & 5 & 2 & 2 \\
\hline
\end{tabular}

new products. The majority of informants said they were concerned about the decline in traditional food plants, mainly because this might lead to hunger, as traditional food plants are their basic food and it is difficult to find alternative products. Paradoxically, when asked about the future, nearly half of the informants expected food habits to change for the better. Regarding preferences in general, several informants mentioned that they would like to have more food and, specifically, more products like rice, maize, and spaghetti, while they would prefer to use less B. senegalensis, Commelina sp., $H$. cannabinus, I. eriocarpa, and Sorghum bicolor (L.) Moench. Finally, all infor- mants said they preferred to have many species, not only to use for eating but also to use in general.

For species reported to be "used a lot" and for which "taste" was given as the primary reason for use, certain personal characteristics of the informants were found to be significantly associated with the responses. There were significant differences between the two villages concerning the use of 11 species and concerning taste for 5 species $\left(G^{2}\right.$, $p<0.01$ ) (Table 3A). People in Silmiogou gave taste as a reason for use more often that people in Ningaré. People in Silmiogou answered "used a lot" more often for 11 spe- 
cies. Similarly, informants with project-contact answered "used a lot" more often for 12 species and stated taste as a reason for use more often for 16 species when compared to informants without project-contact $\left(\mathrm{G}^{2}, \mathrm{p}<0.01\right)$. Five species (D. mespiliformis, L. microcarpa, L. hastata, T. indica, and Z. mauritiana) were used significantly more by people stating that the forest had large importance $\left(\mathrm{G}^{2}\right.$, $p<0.01$ ). The remaining personal characteristics (e.g., ethnic group, age, and religion) were not statistically significant in explaining people's uses and preferences of the studied species.

\section{Species preferences}

When asked to point out the most appreciated species, $A$. digitata, B. costatum, and Corchorus sp. were mentioned most often, both in general and when asked specifically concerning uses in the dry season. The least appreciated species were $B$. senegalensis, Commelina sp., I. eriocar$p a$, and $L$. hastata. In contrast, $B$. aegyptiaca, $C$. sanguinolenta, and $H$. cannabinus were by far the most frequently mentioned as important famine foods, followed by $C$. argentea and I. eriocarpa (Table 3B).

\section{Discussion}

\section{Species use}

The informants reported high use of most of the investigated species, which is in accordance with earlier findings from the study area (Kristensen \& Balslev 2003; Lykke et al. 2004; Smith et al. 1996; Wezel \& Lykke 2006). Differences in use were related to three characteristics: informant's village, project-contact, and view on importance of the forest as a food source. The remaining nine personal characteristics (Table 2) were not important in explaining people's uses and preferences. Other studies have also found differences in use between villages to be more significant than, for example, between age and gender groups (Kristensen \& Lykke 2003). The similarity in answers from the structured questionnaire between, for example, men and women, young and old, different ethnic groups, and religions can be understood by the fact that people eat and live together in large, mixed households. Therefore, they know and use more or less the same species. Other interview studies have shown gender and age differences, with men being more knowledgeable than women (Kristensen \& Balslev 2003), women being more knowledgeable than men (Guissou et al. 2008), differing views between men and women (Wezel \& Haigis 2000), and old people being more knowledgeable than young people (Guissou et al. 2008).

In general, according to the semi-structured part of the interview, people from the more developed village, Silmiogou, and people with project-contact used more of both traditional and modern products, although projects were unrelated to food species. Based on the results of a similar study in Tanzania (Weinberger \& Swai 2006), the villagers of Ningaré, who have less contact with the outside world and are relatively poorer, were expected to use wild resources more than the residents of Silmiogou, but this was not the case. One explanation might be that the greater use of wild plants in Silmiogou is related to people having learned about the value of local food through projects and through other contacts with the outside world. This supports the conclusions by Okafor (1999) about the importance of training and information sharing for increasing the use of wild food plants in rural communities. People who stated from the beginning that they find the forest important as a food source also used more wild plants. This is reflected in a significantly higher use of several wild and fruit-bearing species, e.g., D. mespiliformis, T. indica, and Z. mauritiana.

Among the 26 species included, A. digitata, B. costatum, Corchorus sp., $H$. cannabinus, and $P$. biglobosa seem to be particularly important as food. Adansonia digitata, $B$. costatum, and $P$. biglobosa were previously identified as key species in southern Burkina Faso (Kristensen \& Lykke 2003).

The less appreciated species, often regarded as connected to an old fashioned rural lifestyle, are predominantly small spontaneous herbs, e.g., C. sesamoides, Commelina sp., and I. eriocarpa, but also include two perennials, B. senegalensis and L. hastata. Even though they are less appreciated, these species still have importance as famine foods and medicine. During food shortages, $B$. senegalensis, B. aegyptiaca, and $L$. hastata are priority species in the Sudanian zone of Burkina Faso, e.g., used for vegetable sauce. Most people state that there are no unused wild species since each species has its season, and several are used during famine where people rely on a pool of wild species chosen mainly for their availability (Dei 1988, Thiombiano et al. 2012).

\section{Reasons for using food plants}

Tradition seems to be important when people choose which plants to eat, both regarding single species and food habits in general. Taste was also important, both as a reason for use and as a reason for avoiding certain species. Similar to the pattern for use, it was the informants from Silmiogou and informants with project-contact who more often stated taste as a reason. It could be that a combination of project-contact and a larger variety of food products in Silmiogou (Lykke et al. 2002) relate to increased consciousness about taste in general.

Considerations about health were an important aspect in the selection of food species, which seems justified in a vulnerable area with limited access to medical assistance. That a product was new was not a dominant reason for using it when asked specifically (i.e., $H$. sabdariffa and 
maggi and to a lesser degree $A$. cepa). This is somehow contradicted by the general wish for increased use of new products, but presumably people prefer to use more new products because they find them healthy, they like the taste, and they prefer to improve food security and have variety.

Most of the informants claimed that "no other choice" was not a reason for using a species. "No other choice" can be understood in several ways. When asked specifically for each species in the structured part of the interview, lack of choice was rarely cited. The semi-structured interviews gave additional insight into whether the informant likes the plant or not and whether they find it exchangeable. Some of the less appreciated species, like $C$. sesamoides and Commelina sp., are used less now, presumably reflecting conscious choices. On the other hand, the lack of other possibilities was very important when speaking to people in general.

\section{Change in food habits}

Food habits have changed in people's lifetime; this appeared both when informants were asked about single species and about changes in general. There were some contradictions in people's explanations. On one hand, many informants were concerned about a decline in the use of traditional foods, whereas on the other, people approved of the arrival of new products, were optimistic about the future, and generally found the species easy to get when asked specifically about each species. Regarding changes in vegetation status, a decline in vegetation cover is reported elsewhere from the same area (Lykke et al. 2004) and is also reflected in answers from the structured interviews: the species reported to be harder to obtain are predominantly local trees, while the species perceived as easier to obtain are the newly introduced ones. In light of the importance of wild foods, the decrease in forest cover will reduce the food source considerably, both in daily life and in periods of hunger. People were concerned about this aspect in relation to their health and to food security, although many people expressed optimism, hoping that more new species will be readily available on the local markets in the future, thus providing nutritious alternatives as well as a more varied food base. Even though health is an important criterion for selecting food plants, people do not have information about the nutrition of the available food plants. For instance, people are not aware that many of the introduced products have lower nutritional value than the traditional ones (e.g., P. biglobosa) (Campell-Platt 1980, Glew et al. 1997, Ogoye-Ndegwa \& Aagaard-Hansen 2003), and the local belief that traditional products have inferior nutritive value contradicts much literature (Freiberger et al. 1998; Sena et al. 1998, Smith et al. 1996).

In conclusion, this study showed high importance of local species with people choosing their food plants mainly for health. There seems to be a considerable local interest in both health aspects and food security, and thereby a potential for an increased use of a variety of healthy traditional products, especially if people are better informed about the nutritive qualities of food plants and a sustainable use of resources.

\section{Acknowledgments}

People from Silmiogou and Ningaré are thanked for their cooperation and hospitality. Researchers from Unité de la Formation et de Recherche en Sciences de la Vie et de la Terre, University of Ouagadougou, are thanked for comments and help during fieldwork. Financial support for the Undesert Project (EU-FP7 243906) to AML is highly acknowledged.

\section{Literature Cited}

Alexiades, M. 1996. Selected Guidelines forEthnobotanical Research: A field manual. New York Botanical Garden, Bronx, New York, U.S.A.

APG (Angiosperm Phylogeny Group). 2009. An update of the Angiosperm Phylogeny Group classification for the orders and families of flowering plants: APG III. Botanical Journal of the Linnean Society 161(2):105-121. dx.doi. org/10.1111/j.1095-8339.2009.00996.x

Campell-Platt, G. 1980. African locust bean (Parkia species) and its West African fermented food product, dawadawa. Ecology of Food and Nutrition 9(2):123-132. dx.doi.org/10.1080/03670244.1980.9990590

Dei, G.J.S. 1988. Hunting and gathering in a Ghanaian rain forest community. Ecology of Food and Nutrition 22(3):225-243. dx.doi.org/10.1080/03670244.1989.9991 $\underline{071}$

Flyman, M.V. 2006. A survey of plants used as wild vegetables in four districts of Botswana. Ecology of Food and Nutrition 45(6):405-415. dx.doi. org/10.1080/03670240600985431

Freiberger, C.E., D.J. Vanderjagt, A. Pastuszyn, R.S. Glew, G. Mounkaila, M. Millson \& R.H. Glew. 1998. Nutrient content of the edible leaves of seven wild plants from Niger. Plant Foods for Human Nutrition 53(1):57-69. dx.doi.org/10.1023/A:1008080508028

Ganaba, S., J.-M. Ouadba \& O. Bognounou. 2002. Utilisation des ressources végétales spontanées comme complément alimentaire en région Sahélienne du Burkina Faso. Annales de Botanique de l'Afrique de l'Ouest 2:101-112. 
Glew, R.H., D.J. Vanderjagt, C. Lockett, L.E. Grivetti, G.C. Smith, A. Pastuszyn \& M. Millson. 1997. Amino acid, fatty acid, and mineral composition of 24 indigenous plants of Burkina Faso. Journal of Food Composition and Analysis 10(3):205-217. dx.doi.org/10.1006/jfca.1997.0539

Guinko, S. 1984. Végétation de la Haute-Volta. Dissertation, Bordeaux University III, Bordeaux, France.

Guissou, K.M.L., A.M. Lykke, P. Sankara \& S. Guinko. 2008. Declining wild mushroom recognition and usage in Burkina Faso. Economic Botany 62(3):530-539. dx.doi. org/10.1007/s12231-008-9028-5

Hansen, T.S. \& A. Reenberg. 1998. Approaching local limits to field expansion-Land use pattern dynamics in semi-arid Burkina Faso. Danish Journal of Geography 98(1):56-70. dx.doi.org/10.1080/00167223.1998.106494 $\underline{11}$

Humphry, C.M., M.S. Clegg, C.L. Keen \& L.E. Grivetti. 1993. Food diversity and drought survival. The Hausa example. International Journal of Food Sciences and Nutrition 44(1):1-16. dx.doi.org/10.3109/09637489309017417

Kristensen, M. \& H. Balslev. 2003. Perceptions, use and availability of woody plants among the Gourounsi in Burkina Faso. Biodiversity and Conservation 12(8):1715-1739. dx.doi.org/10.1023/A:1023614816878

Kristensen, M. \& A.M. Lykke. 2003. Informant-based valuation of use and conservation preferences of savanna trees in Burkina Faso. Economic Botany 57(2):203-217. dx.doi.org/10.1663/0013-0001(2003)057[0203:IVOUAC] 2.0.CO;2

Lykke, A.M., O. Mertz \& S. Ganaba. 2002. Food consumption in rural Burkina Faso. Ecology of Food and Nutrition 41(2):119-153. dx.doi.org/10.1080/03670240214492

Lykke, A.M., M.K. Kristensen \& S. Ganaba. 2004. Valuation of local use and dynamics of 56 woody species in the Sahel. Biodiversity and Conservation 13(10):1961-1990. dx.doi.org/10.1023/B:BIOC.0000035876.39587.1a

Mbayngone, E. \& A. Thiombiano. 2011. Dégradation des aires protégées par l'exploitation des ressources végétales: cas de la réserve partielle de faune de Pama, Burkina Faso (Afrique de l'Ouest). Fruits 66(3):187-202. dx.doi.org/10.1051/fruits/2011027

Mertz, O., A.M. Lykke \& A. Reenberg. 2001. Importance of seasonality of vegetable consumption and marketing in Burkina Faso. Economic Botany 55(2):276-289. dx.doi. org/10.1007/BF02864565
Mertz, O. \& A. Reenberg. 1999. Building on diversity: Pathways to agricultural intensification in Burkina Faso. Danish Journal of Geography Special Issue 2:125-137.

Millogo-Rasolodimby, J. \& S. Guinko. 1996. Les plantes ligneuses spontanées à usages culinaires au Burkina Faso. Berichte des Sonderforschingsbereichs 268:125133.

Ntui, V.O., E.A. Uyoh, I.S. Urua, U. Ogbu \& E.C. Okpako. 2012. Regeneration of Parkia biglobosa Benth.: An important tree species of Africa. Journal of Microbiology and Biotechnology Research 2(1):169-177.

Ogoye-Ndegwa, C. \& J. Aagaard-Hansen. 2003. Traditional gathering of wild vegetables among the Luo of western Kenya-A nutritional anthropology project. Ecology of Food and Nutrition 42(1):69-89. dx.doi. org/10.1080/03670240303114

Okafor, O. 1999. The use of farmer knowledge in nonwood forest product research. Pp. 123-132 in Non-Wood Forest Products of Central Africa: Current research issues and prospects for conservation and development. Edited by T.C.H. Sunderland, L.E. Clark \& P. Vantomme. Food and Agriculture Organization of the United Nations, Rome, Italy. www.fao.org/docrep/019/x2161e/x2161e.pdf

Ouédraogo, A., A.M. Lykke, B. Lankoandé \& G. Korbéogo. 2013. Potentials for promoting oil products identified from traditional knowledge of native trees in Burkina Faso. Ethnobotany Research and Applications 11:71-83. http:// journals.sfu.ca/era/index.php/era/article/view/826

Sena, L.P., D.J. Vanderjagt, C. Rivera, A.T.C. Tsin, I. Muhamadu, O. Mahamadou, M. Millson, A. Pastuszyn \& R.H. Glew. 1998. Analysis of nutritional components of eight famine foods of the Republic of Niger. Plant Foods for Human Nutrition 52(1):17-30. dx.doi. org/10.1023/A:1008010009170

Smith, G.C., M.S. Clegg, C.L. Keen \& L.E. Grivetti. 1996. Mineral values of selected plant foods common to southern Burkina Faso and to Niamey, Niger, West Africa. International Journal of Food Sciences and Nutrition 47(1):4153. $\underline{\text { dx.doi.org/10.3109/09637489609028560 }}$

Thiombiano, D.N.E, N. Lamien, D.S. Dibong, I.J. Boussim \& B. Belem. 2012. Le rôle des espèces ligneuses dans la gestion de la soudure alimentaire au Burkina Faso. Sécheresse 23(2):86-93.

Weinberger, K. \& I. Swai. 2006. Consumption of traditional vegetables in central and northeastern Tanzania. Ecology of Food and Nutrition 45(2):87-103. dx.doi. org/10.1080/03670240500530626 
Wezel, A. \& J. Haigis. 2000. Farmers' perception of vegetation changes in semi-arid Niger. Land Degradation and Development 11(6):523-534. dx.doi.org/10.1002/1099145X(200011/12)11:6<523::AID-LDR411>3.0.CO;2-V

Wezel, A. \& A.M. Lykke. 2006. Woody vegetation change in Sahelian West Africa: Evidence from local knowledge.
Environment, Development and Sustainability 8(4):553567. dx.doi.org/10.1007/s10668-006-9055-2

Zerbo, P., J. Millogo-Rasolodimby, O.G. Nacoulma-Ouédraogo \& P. Van Damme. 2011. Plantes médicinales et pratiques médicales au Burkina Faso: Cas des Sanan. Bois et Forêts des Tropiques 307(1):41-53. 
